\title{
Web Yourself to Cease Bleeding
}

\section{Vasudev Ballal'* and Jothi Varghese ${ }^{2}$}

${ }^{1}$ Department of Conservative Dentistry and Endodontics, Manipal College of Dental Sciences, Manipal University, Karnataka, India ${ }^{2}$ Department of Periodontics, Manipal College of Dental Sciences, Manipal University, Karnataka, India

\section{Editorial}

The presence of dust or cob webs, instigate us to quickly pick up the broom and sweep it off. But, hidden amid the grime may be substances of profound value. The ancient Greeks applied cobwebs directly to wounds. Sounds spooky rite? Spider-web silk has attracted the interest of several researchers in recent years because it displays a unique combination of high tensile strength, high breaking strain and ultra low weight. All spider species spin their silk and uses them for a variety of purposes like dragline for safety, web building to trap their prey and also thick cocoon is used by female spiders for protecting their eggs.

Cocoon is basically made up of proteins consisting of various amino acids. Several studies have been performed on the mechanical, physical and chemical properties of silk worm cocoon $[1,2]$. This folk medicine is still practiced by some of the remote Indian villages, wherein the people use cocoon of the spider to arrest the bleeding whenever there is a wound. Till date, no research has been carried out on the intricate properties of cocoon content which aids in cessation of bleeding. Further scientific insights is warranted to identify which integral component of the cocoon is helpful in this beneficial feat, so that it could be used in dentistry as well as in medical field for hemostasis.

\section{References}

1. Chen F, Porter D, Vollrath F (2015) Structural and physical properties of silk worm cocoons. Journal of the Royal Society Interface 2: 1-10.

2. Zhao H, Feng XQ, Yu SW, Cui WZ, Zou FZ (2005) Mechanical properties of silk worm cocoons. Polymer 46: 9192-9201.
*Corresponding author: Vasudev Ballal, Department of Conservative Dentistry and Endodontics, Manipal College of Dental Sciences, Manipal University, Karnataka, India, Tel: 9880626167; E-mail: drballal@yahoo.com, vasudev.ballal@gmail.com

Received January 10, 2015; Accepted January 12, 2015; Published January 18 2015

Citation: Ballal V, Varghese J (2015) Web Yourself to Cease Bleeding. Dentistry 5 e115. doi:10.4172/2161-1122.1000e115

Copyright: ( 2015 Ballal V, et al. This is an open-access article distributed under the terms of the Creative Commons Attribution License, which permits unrestricted use, distribution, and reproduction in any medium, provided the original author and source are credited. 